\title{
ASSESSMENT OF RADIATION AND TEMPERATURE LOADS ON CEMENT COMPOUND CONTAINING SIMULATED RADIOACTIVE WASTE
}

\author{
Varlakov A. P. ${ }^{1}$, Zherebtsov A. A. ${ }^{2}$, Petrov V. G. ${ }^{3}$, Kapustin V. V. ${ }^{1}$, Varlakova G. A. ${ }^{1}$, Vlasova I. E. ${ }^{3}$, \\ Haritonov I. D. ${ }^{3}$, Kalmykov S. N. ${ }^{3}$ \\ 1“A. A. Bochvar High-Technology Research Institute of Inorganic Materials”, Moscow \\ ${ }_{2}^{2}$ JSC “Innovation and Technology Center by “PRORYV” Project”, State Atomic Energy Corporation “Rosatom”, Moscow \\ ${ }^{3}$ Chemistry Department of Moscow State University, Moscow
}

Article received on December 12, 2019

The paper focuses on radiation effects of ionizing sources and elevated temperatures produced on cement compounds containing simulated high-level and intermediate-level LRW. The paper presents the identified physical and chemical properties of the cement compounds and their alterations under the influence of elevated temperatures and ionizing radiation with the absorbed dose of up to $10^{8} \mathrm{~Gy}$.

Keywords: radioactive waste, simulated radioactive waste, radiation stability, dose rate, temperature loads, strength, radionuclide leaching rate.

Radioactive waste (RW) poses a serious threat to the environment and humans and should be converted into a safe form suitable for disposal. Selection of appropriate final waste forms is not an easy task to accomplish, since many factors and combinations of various conditions have to be taken into account. For example, the conditioning process should be simple, reliable, safe, cost-effective and the final waste form should comply with waste acceptance criteria for disposal.

Vitrification and cementing technologies are most commonly applied in different countries around the globe to provide RW immobilization and to obtain suitable final waste form. As a rule, high-level waste is vitrified, whereas intermediateand low-level waste is cemented [1].

Nevertheless, the widespread use of cement materials in various structures of nuclear facilities $[2,3]$ being exposed to high levels of ionizing radiation suggests the ability of cement compound to withstand high dose loads and its potential application as a matrix for high-level waste (HLW) immobilization.

This paper presents a follow up research [4-6] on the comprehensive assessment of changes in the standardized properties, phase composition and microstructure of cement compounds occurring under the influence of high doses of ionizing radiation equivalent to those emitted by HLW during its storage.

Current stage of research addresses heat release impacting cement compound hardening and various types of ionizing radiation affecting it involving simulated nitrate-containing high-level LRW (HLW simulator) and genuine nitrate-containing intermediate-level LRW. To address this task, mechanical, physical and chemical parameters of cement compounds hardening at elevated temperatures and cement compounds after being exposed to gamma-, alpha- radiation and electrons were studied. 


\section{Subjects and research methods}

The studies involved samples of cement compounds fabricated from Portland cement (PC) either with some amounts of bentonite clay powder (DB) being added or with no additives and with a grouting fluid. Tap water, simulated HLW and genuine LRW at a water-cement ratio (W/C) of 0.5 were used as grouting fluid. Bentonite clay powder was introduced with the Portland cement and was taken into account under the $\mathrm{W} / \mathrm{C}$ ratio as $\mathrm{C}=95 \% \mathrm{PC}+5 \% \mathrm{DB}$.

Simulated HLW had a salinity of $530 \mathrm{~g} / \mathrm{l}$ and a composition corresponding to the average composition of the waste generated at PA Mayak [7], g/l: $\mathrm{NaOH}-1$ 196.8; $\mathrm{NaNO}_{3}-209.1 ; \mathrm{NaNO}_{2}-108.1$; $\mathrm{NaHCO}_{3}-17.64 ; \mathrm{K}_{2} \mathrm{Cr}_{2} \mathrm{O}_{7}-10.82 ; \mathrm{KCl}-1.47$; $\mathrm{Zn}\left(\mathrm{NO}_{3}\right)_{2}-0.02 ; \mathrm{Pb}\left(\mathrm{NO}_{3}\right)_{2}-0.07 ; \mathrm{CsCl}-0.05$; $\mathrm{SrCl}_{2}-0.5$. Genuine LRW had the following composition, $\mathrm{g} / \mathrm{l}: \mathrm{Cl}^{-}-9.2 ; \mathrm{NO}_{3}^{-}-71.1 ; \mathrm{ClO}_{4}^{-}-4.3 ; \mathrm{Na}^{+}-$ 187.2. LRW activity was associated with the following radionuclides, $\mathrm{Bq} / \mathrm{L}:{ }^{137} \mathrm{Cs}-2 \cdot 10^{6},{ }^{90} \mathrm{Sr}-3 \cdot 10^{6}$, ${ }^{239} \mathrm{Pu}-1 \cdot 10^{5},{ }^{152} \mathrm{Eu}-3 \cdot 10^{5}$. According to regulatory requirements, the LRW refers to the intermediatelevel waste category.

Thus, the studies were performed based on cement compound samples indicated in Table 1.

\section{Table 1. Cement compound compositions}

\begin{tabular}{|c|c|c|c|c|}
\hline Composition & $\begin{array}{c}\text { Bonding } \\
\text { agent }\end{array}$ & Additive & Grouting fluid & W/C \\
\hline № 1 & PC & - & water & 0.5 \\
\hline № 2 & PC & DB & water & 0.5 \\
\hline № 3 & PC & - & Simulator, s/c $530 \mathrm{~g} / \mathrm{l}$ & 0.5 \\
\hline № 4 & PC & DB & Simulator, s/c $530 \mathrm{~g} / \mathrm{l}$ & 0.5 \\
\hline № 5 & PC & - & LRW & 0.5 \\
\hline № 6 & PC & DB & LRW & 0.5 \\
\hline
\end{tabular}

$\mathrm{PC}$ - Portland cement, DB - bentonite clay powder, W/C - water-cement ratio, $s / c$ - salt content

To evaluate mechanical, physical and chemical properties of cement compounds, compressive strength was measured using standard methods and equipment described previously in [4, 5]. Solidification and hardening of cement compounds occurred under air-wet conditions both at a room temperature and at elevated temperatures of 50 and $90^{\circ} \mathrm{C}$, under prolonged exposure to water, alternating freezing/thawing cycles and radiation exposure.

The cement samples were exposed to radiation in a gamma chamber fitted with a ${ }^{137} \mathrm{Cs}$ radiation source of $661 \mathrm{keV}$. Exposure times corresponded to those required for the absorbed dose to reach $10^{6}$, $10^{7}$ and $10^{8} \mathrm{~Gy}$, respectively. Electron exposure was studied using UELV-10-10-S-70 linear electron accelerator characterized with the following parameters: energy $-8 \mathrm{MeV}$, pulse duration $-6 \mu \mathrm{s}$, pulse repetition frequency $-300 \mathrm{~Hz}$, average beam current $-\leqslant 800 \mu \mathrm{A}$, sweep width $-245 \mathrm{~mm}$, sweep frequency $-1 \mathrm{~Hz}$. Depending on how fast the sample passed through the electron beam, the dose rate averaged $1.2 \mathrm{kGy} / \mathrm{s}$. Irradiation with alpha-emitters was carried out by injecting the ${ }^{239} \mathrm{Pu}$ radionuclide (a nitric acid solution) directly into the grouting fluid. The dose rates of $10^{6}, 10^{7}, 10^{8} \mathrm{~Gy}$ in the cement compound samples were reached following their exposure for 90 days under activity of ${ }^{239} \mathrm{Pu}$ per compound sample of $3.5 \cdot 10^{8}, 3.9 \cdot 10^{9}$ and $2.4 \cdot 10^{10} \mathrm{~Bq}$, respectively.

Radionuclides leaching rate was evaluated according to a standard method [8] in a thermostat under static conditions at a temperature of $25^{\circ} \mathrm{C}$. Deionized water (with a conductivity of $18 \mathrm{Mohm} / \mathrm{cm}$ ) was used as a leaching medium. To evaluate the content of $\mathrm{Cs}, \mathrm{Sr}, \mathrm{Pu}$ radionuclides in leach waters, a gamma spectrometer with a high-purity germanium detector Canberra GC 3020 (Canberra, USA) and a Tri-Carb 2810T liquid scintillation spectrometer (Perkin Elmer, USA) were used.

Mechanical, physical and chemical property indicators of the compounds were identified according to the following flow chart: compressive strength hardening time of 7, 14, 28 days; frost resistance hardening time of 28 days; water resistance of samples (resistance to prolonged exposure in water for 90 days) - from the hardening time of 28 days; radiation resistance of the samples and radionuclide leaching rate - from the hardening time of 28 days. Measurements and tests involved cube $(2 \times 2 \times 2 \mathrm{~cm})$ and beam $-(1 \times 1 \times 3 \mathrm{~cm})$ shaped samples.

\section{Results and discussion}

Tables 2 and 3 present the data on physical and mechanical properties and estimated leaching rates for unirradiated cement compounds. They also present the compressive strengths of samples that have gained strength at elevated temperatures, after being subject to 30 cycles of freezing/thawing and exposed in an aqueous medium. All the values identified are average values obtained from two parallel measurements.

Measured compressive strengths of cement compound samples, the hardening of which took place at temperatures of 50 and $90^{\circ} \mathrm{C}$, did not show any negative effects of elevated temperature both on the common solidification process and the values being considered typical for the strength development periods. The strength of the compounds 
Table 2. Mechanical compressive strength of cement compounds that gained strength at different temperatures following frost and water resistance tests

\begin{tabular}{|c|c|c|c|c|c|c|c|c|}
\hline \multirow{3}{*}{$\begin{array}{l}\text { 흘 } \\
\text { 흘 } \\
\text { 응 }\end{array}$} & \multirow{3}{*}{ 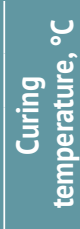 } & \multicolumn{7}{|c|}{ Mechanical strength of the compound, MPa (average measurement) } \\
\hline & & \multicolumn{3}{|c|}{ Hardened under air-wet conditions } & \multicolumn{2}{|c|}{ During frost resistance testing } & \multicolumn{2}{|c|}{ During water resistance testing } \\
\hline & & Day 7 & Day 14 & Day 28 & $\begin{array}{l}\text { Control compound } \\
\text { with similar hardening } \\
\text { age }\end{array}$ & $\begin{array}{c}\text { Following } \\
30 \text { freezing/thawing } \\
\text { cycles }\end{array}$ & $\begin{array}{l}\text { Control compound } \\
\text { with similar hardening } \\
\text { age }\end{array}$ & $\begin{array}{c}\text { After being } \\
\text { held in watel } \\
\text { for } 90 \text { days }\end{array}$ \\
\hline 1 & \multirow{4}{*}{25} & $17.9 \pm 4.5$ & $26.4 \pm 6.6$ & $33.8 \pm 8.5$ & $35.7 \pm 8.9$ & $33.8 \pm 8.5$ & $41.4 \pm 10.4$ & $35.8 \pm 9.0$ \\
\hline 2 & & $16.8 \pm 4.2$ & $25.0 \pm 6.3$ & $32.7 \pm 8.2$ & $35.2 \pm 8.8$ & $33.1 \pm 8.3$ & $41.1 \pm 10.3$ & $35.1 \pm 8.8$ \\
\hline 3 & & $13.3 \pm 3.3$ & $21.2 \pm 5.3$ & $27.7 \pm 6.9$ & $29.1 \pm 7.3$ & $26.8 \pm 6.7$ & $32.5 \pm 8.1$ & $27.6 \pm 6.9$ \\
\hline 4 & & $12.2 \pm 3.1$ & $20.0 \pm 5.0$ & $27.2 \pm 6.8$ & $28.4 \pm 7.1$ & $26.5 \pm 6.6$ & $32.0 \pm 8.0$ & $27.1 \pm 6.8$ \\
\hline 1 & \multirow{4}{*}{50} & $18.3 \pm 4.6$ & $26.9 \pm 6.7$ & $34.7 \pm 8.7$ & $35.9 \pm 9.0$ & $34.0 \pm 8.5$ & $41.6 \pm 10.4$ & $35.7 \pm 8.9$ \\
\hline 2 & & $17.1 \pm 4.3$ & $26.2 \pm 6.6$ & $33.8 \pm 8.5$ & $35.6 \pm 8.9$ & $33.8 \pm 8.5$ & $41.5 \pm 10.4$ & $35.5 \pm 8.9$ \\
\hline 3 & & $14.9 \pm 3.7$ & $22.8 \pm 5.7$ & $29.1 \pm 7.3$ & $30.0 \pm 7.5$ & $27.3 \pm 6.8$ & $33.0 \pm 8.3$ & $27.2 \pm 6.8$ \\
\hline 4 & & $13.5 \pm 3.4$ & $21.3 \pm 5.3$ & $28.2 \pm 7.1$ & $29.7 \pm 7.4$ & $26.9 \pm 6.7$ & $32.9 \pm 8.2$ & $27.1 \pm 6.8$ \\
\hline 1 & \multirow{4}{*}{90} & $19.2 \pm 4.8$ & $29.9 \pm 7.5$ & $35.5 \pm 8.9$ & $36.2 \pm 9.1$ & $34.4 \pm 8.6$ & $40.9 \pm 10.2$ & $35.3 \pm 8.8$ \\
\hline 2 & & $19.6 \pm 4.9$ & $28.3 \pm 7.1$ & $34.8 \pm 8.7$ & $35.8 \pm 9.0$ & $34.1 \pm 8.5$ & $40.7 \pm 10.2$ & $34.9 \pm 8.7$ \\
\hline 3 & & $15.5 \pm 3.9$ & $23.5 \pm 5.9$ & $30.6 \pm 7.7$ & $31.3 \pm 7.8$ & $28.5 \pm 7.1$ & $33.2 \pm 8.3$ & $28.1 \pm 7.0$ \\
\hline 4 & & $14.4 \pm 3.6$ & $23.1 \pm 5.8$ & $29.5 \pm 7.4$ & $31.0 \pm 7.8$ & $28.0 \pm 7.0$ & $33.1 \pm 8.3$ & $28.4 \pm 7.1$ \\
\hline
\end{tabular}

Table 3. ${ }^{137} \mathrm{Cs},{ }^{90} \mathrm{Sr}$ and ${ }^{239} \mathrm{Pu}$ leaching rates at the 28 th day of the experiment involving samples have gained their strength under different temperatures

\begin{tabular}{|c|c|c|c|c|}
\hline \multirow{2}{*}{ Composition } & \multirow{2}{*}{$\begin{array}{c}\text { Curing } \\
\text { temperature, }{ }^{\circ} \mathrm{C}\end{array}$} & \multicolumn{3}{|c|}{ Leaching rate, $\mathrm{g} / \mathrm{cm}^{2} \cdot$ day } \\
\hline & & ${ }^{137} C_{s}$ & ${ }^{90} \mathrm{Sr}$ & ${ }^{239} \mathrm{Pu}$ \\
\hline 1 & \multirow{4}{*}{25} & $7.1 \cdot 10^{-5}$ & $9.7 \cdot 10^{-6}$ & $3.1 \cdot 10^{-6}$ \\
\hline 2 & & $5.6 \cdot 10^{-5}$ & $8.4 \cdot 10^{-6}$ & $9.6 \cdot 10^{-7}$ \\
\hline 3 & & $2.2 \cdot 10^{-4}$ & $4.5 \cdot 10^{-5}$ & $5.8 \cdot 10^{-6}$ \\
\hline 4 & & $8.3 \cdot 10^{-5}$ & $2.7 \cdot 10^{-5}$ & $5.1 \cdot 10^{-6}$ \\
\hline 1 & \multirow{4}{*}{50} & $2.5 \cdot 10^{-5}$ & $5.1 \cdot 10^{-6}$ & $1.2 \cdot 10^{-6}$ \\
\hline 2 & & $1.8 \cdot 10^{-5}$ & $3.7 \cdot 10^{-6}$ & $8.9 \cdot 10^{-7}$ \\
\hline 3 & & $9.1 \cdot 10^{-5}$ & $1.3 \cdot 10^{-5}$ & $4.0 \cdot 10^{-6}$ \\
\hline 4 & & $6.3 \cdot 10^{-5}$ & $9.3 \cdot 10^{-6}$ & $4.8 \cdot 10^{-6}$ \\
\hline 1 & \multirow{4}{*}{90} & $3.4 \cdot 10^{-5}$ & $3.1 \cdot 10^{-6}$ & $9.1 \cdot 10^{-7}$ \\
\hline 2 & & $2.1 \cdot 10^{-5}$ & $1.8 \cdot 10^{-6}$ & $7.5 \cdot 10^{-7}$ \\
\hline 3 & & $7.0 \cdot 10^{-5}$ & $1.0 \cdot 10^{-5}$ & $2.2 \cdot 10^{-6}$ \\
\hline 4 & & $3.9 \cdot 10^{-5}$ & $7.2 \cdot 10^{-6}$ & $2.6 \cdot 10^{-6}$ \\
\hline
\end{tabular}

varied over time depending on their composition and growed due to hydration processes occurring in the cement stone. These results generally correlate with previously published studies referring to the influence of ambient temperature on the cement stone hardening $[9,10]$.

The following points can be emphasized based on the results obtained. Strength development of cement stone accelerates with an increase in the curing temperatures, provided that the required humidity is maintained in the thermostat. It was demonstrated that under these conditions, bentonite clay powder addition cannot produce any pronounced effect on the strength characteristics. The strength of cement compound samples involving simulated HLW appears to be $20-25 \%$ lower as compared to cement compounds produced by mixing with distilled water.

Under considered conditions, cement compounds meet the requirements [11] on the acceptable strength of cemented waste $(5 \mathrm{MPa})$ starting from a hardening time of 7 days. Moreover, strength loss due to freezing/thawing and prolonged exposure to water does not exceed $25 \%$ compared to the control sample having the same hardening age. In terms of strength, the tested samples meet the acceptance criteria [12] for RW class $2-$ not less than $10 \mathrm{MPa}$ with a test-driven strength loss of no more than $20 \%$ of the established value. Thus, the considered cement compounds comply with strength criterion specified by relevant regulations governing activities at nuclear facilities.

Basically, cement compounds involving bentonite clay additive (No. 2 and No. 4) differ from those with no additives (No. 1 and No. 3) by lower ${ }^{137} \mathrm{Cs}$, ${ }^{90} \mathrm{Sr}$ and ${ }^{239} \mathrm{Pu}$ leaching rates (with an up to $30 \%$ discrepancy) (see Table 3), which is also true for samples that gained their strength at temperatures of 50 and $90^{\circ} \mathrm{C}$. It may be also noted that during cement compound hardening, an increase in the ambient temperature of up to $90^{\circ} \mathrm{C}$ produced no negative effect on the chemical resistance: no increase in the radionuclide leaching rate was observed. 
To evaluate the radiation resistance, cement compounds were exposed to various types of ionizing radiation. Subsequently, cement compound samples were tested to measure their frost and water resistances, as well as the radionuclide leaching rate.

Table 4 presents the experimental data on the strength of the samples after their exposure to gamma radiation and electrons.

\section{Table 4. Mechanical compressive strengths of cement compounds subjected to radiation exposure}

\begin{tabular}{|c|c|c|c|c|c|c|}
\hline \multirow{3}{*}{$\begin{array}{l}\text { 을 } \\
\text { : } \\
\text { 을 }\end{array}$} & \multicolumn{6}{|c|}{ Mechanical strength of the compound, MPa } \\
\hline & \multicolumn{3}{|c|}{ Gamma-quants } & \multicolumn{3}{|c|}{ Electrons } \\
\hline & $10^{6} \mathrm{~Gy}$ & $10^{7} \mathrm{~Gy}$ & $10^{8} \mathrm{~Gy}$ & $10^{6} \mathrm{~Gy}$ & $10^{7} \mathrm{~Gy}$ & $10^{8} \mathrm{~Gy}$ \\
\hline \multicolumn{7}{|c|}{ Irradiated cement compounds } \\
\hline 1 & $34.9 \pm 8.7$ & $35.2 \pm 8.8$ & $34.5 \pm 8.6$ & $36.6 \pm 9.2$ & $37.1 \pm 9.3$ & $35.4 \pm 8.9$ \\
\hline 2 & $34.6 \pm 8.7$ & $36.3 \pm 9.1$ & $35.1 \pm 8.8$ & $35.9 \pm 9.0$ & $37.4 \pm 9.4$ & $36.6 \pm 9.2$ \\
\hline 3 & $29.5 \pm 7.4$ & $28.0 \pm 7.0$ & $29.0 \pm 7.3$ & $30.6 \pm 7.7$ & $31.2 \pm 7.8$ & $31.9 \pm 8.0$ \\
\hline 4 & $29.3 \pm 7.3$ & $29.7 \pm 7.4$ & $28.7 \pm 7.2$ & $29.8 \pm 7.5$ & $31.8 \pm 8.0$ & $31.7 \pm 7.9$ \\
\hline \multicolumn{7}{|c|}{ During frost resistance testing after irradiation } \\
\hline 1 & $32.5 \pm 8.1$ & $33.2 \pm 8.3$ & $33.4 \pm 8.4$ & $34.5 \pm 8.6$ & $35.0 \pm 8.8$ & $34.4 \pm 8.6$ \\
\hline 2 & $31.8 \pm 8.0$ & $33.5 \pm 8.4$ & $33.0 \pm 8.3$ & $33.8 \pm 8.5$ & $34.4 \pm 8.6$ & $33.3 \pm 8.3$ \\
\hline 3 & $27.4 \pm 6.9$ & $28.8 \pm 7.2$ & $28.7 \pm 7.2$ & $29.1 \pm 7.3$ & $29.3 \pm 7.3$ & $29.9 \pm 7.5$ \\
\hline 4 & $26.7 \pm 6.7$ & $28.5 \pm 7.1$ & $28.4 \pm 7.1$ & $29.4 \pm 7.4$ & $29.7 \pm 7.4$ & $29.3 \pm 7.3$ \\
\hline \multicolumn{7}{|c|}{ During water resistance testing after irradiation } \\
\hline 1 & $35.1 \pm 8.8$ & $34.1 \pm 8.5$ & $35.4 \pm 8.9$ & $33.2 \pm 8.3$ & $33.5 \pm 8.4$ & $34.4 \pm 8.6$ \\
\hline 2 & $35.2 \pm 8.8$ & $34.5 \pm 8.6$ & $35.3 \pm 8.8$ & $32.6 \pm 8.2$ & $33.3 \pm 8.3$ & $34.1 \pm 8.5$ \\
\hline 3 & $30.3 \pm 7.6$ & $29.6 \pm 7.4$ & $31.1 \pm 7.8$ & $28.5 \pm 7.1$ & $29.0 \pm 7.3$ & $30.5 \pm 7.6$ \\
\hline 4 & $29.7 \pm 7.4$ & $28.5 \pm 7.1$ & $30.9 \pm 7.7$ & $28.6 \pm 7.2$ & $28.3 \pm 7.1$ & $30.4 \pm 7.6$ \\
\hline
\end{tabular}

Table 4 demonstrates that radiation exposure associated with gamma-quanta and electrons did not cause a compressive strength loss below the established limits and exceeding the established discrepancy of $20 \%$.

These findings demonstrate that the studied cement compounds do not lose their strength capacity upon their gamma-quanta and electron exposure to a dose of $10^{8} \mathrm{~Gy}$.

Effects of alpha radiation were investigated for compounds No. 1 and No. 3. Upon samples receipt, ${ }^{239} \mathrm{Pu}$ was introduced into the grouting fluid; the exposure time for all samples accounted for 90 days. The experiments showed that at the highest cumulated dose of alpha radiation corresponding to $10^{8} \mathrm{~Gy}$, the strength of the samples did not change (within the measurement error) amounting to $35.7 \pm 8.9 \mathrm{MPa}$ and $26.9 \pm 6.7 \mathrm{MPa}$ for compositions No. 1 and No. 3, respectively.

Apparently, there are no fundamental differences in the radiation effects resulting from different sources of ionizing radiation, at least up to an exposure dose of $10^{8} \mathrm{~Gy}$.

Samples of cement compounds (compositions No. 5 and No.6) involving LRW were studied to measure their mechanical strength, chemical resistance and resistance to radiation exposure. To accumulate a dose corresponding to $10^{8} \mathrm{~Gy}$, the samples were exposed to external gamma and electron irradiation. Table 5 presents the results of the cement compound testing.

Table 5. Mechanical compressive strength of cement compounds involving $L R W$ during tests focused on frost and water resistance before and after their irradiation

\begin{tabular}{|c|c|c|c|c|}
\hline \multirow{2}{*}{$\begin{array}{l}\text { 을 } \\
\text { 흥 } \\
\text { 흥 }\end{array}$} & \multirow[b]{2}{*}{ Dose, Gy } & \multicolumn{3}{|c|}{ Mechanical strength of the compound, $\mathrm{MPa}$} \\
\hline & & $\begin{array}{l}\text { Hardened } \\
\text { under air-wet } \\
\text { conditions }\end{array}$ & $\begin{array}{c}\text { Following } \\
30 \text { freezing/ } \\
\text { thawing cycles }\end{array}$ & $\begin{array}{l}\text { After being } \\
\text { held in water } \\
\text { for } 90 \text { days }\end{array}$ \\
\hline \multirow[b]{2}{*}{5} & 0 & $35.8 \pm 9.0$ & $33.4 \pm 8.4$ & $31.0 \pm 7.8$ \\
\hline & $10^{8}$ (electrons) & $36.7 \pm 9.2$ & $32.2 \pm 8.1$ & $29.7 \pm 7.4$ \\
\hline & $10^{8}$ (gamma) & $34.9 \pm 8.7$ & $33.1 \pm 8.3$ & $28.7 \pm 7.2$ \\
\hline \multirow{3}{*}{6} & 0 & $34.3 \pm 8.6$ & $32.5 \pm 8.1$ & $29.2 \pm 7.3$ \\
\hline & $10^{8}$ (electrons) & $33.9 \pm 8.5$ & $31.6 \pm 7.9$ & $30.1 \pm 7.5$ \\
\hline & $10^{8}$ (gamma) & $32.6 \pm 8.2$ & $31.1 \pm 7.8$ & $28.8 \pm 7.2$ \\
\hline
\end{tabular}

Table 6 presents the results of ${ }^{137} \mathrm{Cs}$, ${ }^{90} \mathrm{Sr}$ and ${ }^{239} \mathrm{Pu}$ leaching tests with irradiated samples.

Table 6. Leaching rate of ${ }^{137} \mathrm{Cs},{ }^{90} \mathrm{Sr}$ and ${ }^{239} \mathrm{Pu}$ from irradiated samples on the 28th day

\begin{tabular}{|c|c|c|c|c|}
\hline \multirow{2}{*}{$\begin{array}{l}\text { Compo- } \\
\text { sition }\end{array}$} & \multirow{2}{*}{$\begin{array}{c}\text { Exposure dose } \\
\text { Gy }\end{array}$} & \multicolumn{3}{|c|}{ Leaching rate, $\mathrm{g} / \mathrm{cm}^{2}$.day } \\
\hline & & ${ }^{137} \mathrm{Cs}$ & ${ }^{90} \mathrm{Sr}$ & ${ }^{239} \mathrm{Pu}$ \\
\hline \multirow{3}{*}{1} & 0 & $2.2 \cdot 10^{-4}$ & $9.7 \cdot 10^{-6}$ & $3.1 \cdot 10^{-6}$ \\
\hline & $10^{8}$ (electrons) & $7.0 \cdot 10^{-5}$ & $8.2 \cdot 10^{-6}$ & $1.2 \cdot 10^{-6}$ \\
\hline & $10^{8}$ (gamma) & $9.1 \cdot 10^{-5}$ & $4.3 \cdot 10^{-6}$ & $8.5 \cdot 10^{-7}$ \\
\hline \multirow{3}{*}{2} & 0 & $7.1 \cdot 10^{-5}$ & $4.5 \cdot 10^{-6}$ & $5.8 \cdot 10^{-6}$ \\
\hline & $10^{8}$ (electrons) & $4.4 \cdot 10^{-5}$ & $2.5 \cdot 10^{-6}$ & $8.6 \cdot 10^{-6}$ \\
\hline & $10^{8}$ (gamma) & $2.9 \cdot 10^{-5}$ & $1.3 \cdot 10^{-6}$ & $1.2 \cdot 10^{-7}$ \\
\hline \multirow{3}{*}{3} & 0 & $9.0 \cdot 10^{-5}$ & $1.2 \cdot 10^{-5}$ & $1.4 \cdot 10^{-6}$ \\
\hline & $10^{8}$ (electrons) & $7.9 \cdot 10^{-5}$ & $8.8 \cdot 10^{-6}$ & $1.5 \cdot 10^{-6}$ \\
\hline & $10^{8}$ (gamma) & $9.1 \cdot 10^{-5}$ & $9.5 \cdot 10^{-6}$ & $9.8 \cdot 10^{-7}$ \\
\hline \multirow{3}{*}{4} & 0 & $8.1 \cdot 10^{-5}$ & $9.4 \cdot 10^{-6}$ & $1.1 \cdot 10^{-6}$ \\
\hline & $10^{8}$ (electrons) & $7.2 \cdot 10^{-5}$ & $6.8 \cdot 10^{-6}$ & $8.9 \cdot 10^{-7}$ \\
\hline & $10^{8}$ (gamma) & $6.8 \cdot 10^{-5}$ & $7.9 \cdot 10^{-6}$ & $7.5 \cdot 10^{-7}$ \\
\hline \multirow{3}{*}{5} & 0 & $9.0 \cdot 10^{-5}$ & $1.2 \cdot 10^{-5}$ & $1.4 \cdot 10^{-6}$ \\
\hline & $10^{8}$ (electrons) & $7.9 \cdot 10^{-5}$ & $8.8 \cdot 10^{-6}$ & $1.5 \cdot 10^{-6}$ \\
\hline & $10^{8}$ (gamma) & $9.1 \cdot 10^{-5}$ & $9.5 \cdot 10^{-6}$ & $9.8 \cdot 10^{-7}$ \\
\hline \multirow{3}{*}{6} & 0 & $8.1 \cdot 10^{-5}$ & $9.4 \cdot 10^{-6}$ & $1.1 \cdot 10^{-6}$ \\
\hline & $10^{8}$ (electrons) & $7.2 \cdot 10^{-5}$ & $6.8 \cdot 10^{-6}$ & $8.9 \cdot 10^{-7}$ \\
\hline & $10^{8}$ (gamma) & $6.8 \cdot 10^{-5}$ & $7.9 \cdot 10^{-6}$ & $7.5 \cdot 10^{-7}$ \\
\hline
\end{tabular}


It can be noted that ${ }^{137} \mathrm{Cs},{ }^{90} \mathrm{Sr}$ and ${ }^{239} \mathrm{Pu}$ leaching rate slightly decreases with an increase in the exposure dose and continues to decrease following the introduction of bentonite clay powder. No dependence between the exposure type and the leaching rate from the studied cement compounds could be identified. For all sample compositions, the leaching rates do not exceed the regulatory limits specified for cemented RW.

\section{Conclusions}

The research performed shows that cement compounds with HLW simulator and genuine intermediate-level LRW retain their physical and mechanical characteristics both under thermal loads (up to a temperature of $90^{\circ} \mathrm{C}$ ) during sample solidification and dose loads of up to $10^{8} \mathrm{~Gy}$ under long-term water exposure and alternate freezing/thawing cycles. An increase in the ambient temperature (up to $90^{\circ} \mathrm{C}$ ) accelerates cement hardening at its early stage, provided that the required humidity is maintained in the thermostat. Radionuclide leaching rate can be reduced to up to $30 \%$ by introducing some bentonite clay (5 wt.\%). Moreover, maximum leaching rate for almost all samples, including the irradiated ones, did not exceed $10^{-4} \mathrm{~g} /\left(\mathrm{cm}^{2} \cdot\right.$ day $)$ for cesium, $10^{-5} \mathrm{~g} /\left(\mathrm{cm}^{2}\right.$.day) for strontium, and $10^{-5} \mathrm{~g} /\left(\mathrm{cm}^{2} \cdot\right.$ day $)$ for plutonium. An increase in the cement hardening temperature did not produce any significant effect on the radionuclides leaching rate.

Thus, the test of Portland cement-based compounds being mixed either with water or simulated HLW and intermediate-level LRW provide no evidence obstructing their consideration as a suitable matrix for HLW immobilization.

\section{References}

1. Ojovan M. I., Lee W. E., Kalmykov S. N. An introduction to nuclear waste immobilisation. Elsevier, 2019.

2. Mobasher N., Bernal S. A., Kinoshita H., Sharrad C. A., Provisa J. L. Gamma irradiation resistance of an early age slag-blended cement matrix for nuclear waste encapsulation. J. Mater. Res., 2015, vol. 30, no. 9, pp. 1563-1571.

3. Glasser F. P. Characterisation of the barrier performance of cements. MRS Symp. Proc., 2002, vol. 713, pp. 721-732.

4. Varlakov A. P., Kapustin V. V., Varlakova G. A., Zherebcov A. A., Petrov V. G., Shirshin E. A.,
Kalmykov S. N. Vliyanie radiacionnyh nagruzok, harakternyh dlya vysokoaktivnyh othodov, na svojstva cementnoj matricy [The effect of radiation doses typical for high-level waste on the properties of the cement matrix]. Radioaktivnye othody - Radioactive Waste, 2018, no. 1(2), pp. 89-96.

5. Varlakov A. P., Zherebtsov A. A., Petrov V. G., Kapustin V. V., Varlakova G. A., Vlasova I. E., Kalmykov S. N. Povedenie cementnoj matricy pod vozdejstviem radiacionnyh nagruzok [Behavior of Cement-Based Matrices Exposed to Radiation]. Voprosy radiacionnoj bezopasnosti - Radiation Safety Issues, 2018, no. 3, pp. 13-20.

6. Varlakov A., Zherebtsov A., Kapustin V., Varlakova G., Petrov V., Vlasova I., Shirshin E., Kalmykov S. Characteristics of cement compounds after irradiation up to doses typical for high level radioactive waste. 3nd International Symposium on cement-based materials for Nuclear Waste. NUWCEM 2018. 24-26 October 2018, Avignon, France. Book of Abstracts. P. 103.

7. Vinokurov S. E., Kulyako Yu. M., Slyuntchev O. M., Rovny S. I., Myasoedov B. F. Low-temperature immobilization of actinides and other components of highlevel waste in magnesium potassium phosphate matrices. J. of Nuclear Materials. 2009, vol. 385, pp. 189-192. 8. GOST R 52126-2003. Othody radioaktivnye. Opredelenie himicheskoj ustojchivosti otverzhdennyh vysokoaktivnyh othodov metodom dlitel'nogo vyshchelachivaniya [State Standard R 52126-2003. Radioactive waste. Long time leach testing of solidified radioactive waste forms]. Moscow, Gosstandart Rossii Publ., 2003.

9. Volzhenskiy A. V. Mineral'nye vyazhushchie veshchestva [Mineral binders]. Moscow, Stroyizdat Publ, 1986. $464 \mathrm{p}$.

10. Rybiev I. A. Stroitel'noe materialovedenie [Building materials]. Moscow, Vysshaya shkola Publ., 2004. $701 \mathrm{p}$.

11. GOST $R$ 51883-2002. Othody radioaktivnye cementirovannye. Obshchie tekhnicheskie trebovaniya [State Standard R 51883-2002. Cemented radioactive waste. General technical requirements]. Moscow, Gosstandart Rossii Publ., 2002.

12. Federalnye normy i pravila v oblasti ispolzovaniya atomnoj energii "Kriterii priemlemosti radioaktivnyh othodov dlya zahoroneniya" (NP-093-14) / Utv. Prikazom Federalnoj sluzhby po ekologicheskomu, tehnologicheskomu i atomnomu nadsoru ot 15.12.2014, N 572 [NP-093-14 Criteria for acceptance of radioactive waste for disposal]. Moscow, 2014. $43 \mathrm{p}$.

Varlakov Andrey Petrovich, Doctor of Sciences, Director of Department, JSC “VNIINM" (5a, Rogova St., Moscow, 123098, Russia), e-mail: APVarlakov@bochvar.ru. 
Zherebtsov Alexander Anatolevich, PhD, Head of Department, JSC "PRORYV" (2/8, Malaya Krasnoselskaya St., Moscow, 107140, Russia), e-mail: zhala@proryv2020.ru.

Petrov Vladimir Gennadevich, PhD, Associate Professor, Lomonosov Moscow State University (1, Leninskie gory St., Moscow, 119991, Russia), e-mail: Vladimir.g.petrov@gmail.com.

Kapustin Vitaliy Victorovich, Lead Engineer, JSC “VNIINM" (5a, Rogova St., Moscow, 123098, Russia), email: vitkap1990@gmail.com.

Varlakova Galina Andreevna, PhD, Main Specialist, ISC “VNIINM” (5a, Rogova St., Moscow, 123098, Russia), e-mail: Varlakova@inbox.ru.

Vlasova Irina Engelsovna, PhD, Senior Researcher, Lomonosov Moscow State University (1, Leninskie gory St., Moscow, 119991, Russia), e-mail: irinaeng@gmail.com.

Haritonov Ivan Dmitrievich, Postgraduate Student, Lomonosov Moscow State University (1, Leninskie gory St., Moscow, 119991, Russia), e-mail: ob-ivan@ya.ru.

Kalmykov Stepan Nikolaevich, Doctor of Sciences, Acting Dean of Chemical Faculty of MSU, Lomonosov Moscow State University (1, Leninskie gory St., Moscow, 119991, Russia), e-mail: stepan@radio.chem.msu.ru.

\section{Bibliographic description}

Varlakov A. P., Zherebtsov A. A., Petrov V. G., Kapustin V. V., Varlakova G. A., Vlasova I. E., Haritonov I. D., Kalmykov S. N. Assessment of Radiation and Temperature Loads on Cement Compound Containing Simulated Radioactive Waste. Radioactive Waste, 2020, no. 1 (10), pp. 66-72. (In Russian). DOI: 10.25283/2587-9707-2020-1-66-72. 